\title{
Mismatches in Teachers' Teaching and Students' Learning Styles in English Classes at a Secondary School Level: A Case Study of Laotian Secondary Schools
}

\section{Souksakhone Sengsouliya ${ }^{1} *$, Sithane Soukhavong ${ }^{1}$, Say Phonekeo $^{1}$, Souk Sengsouliya $^{1}$, \&}

\author{
Toby Xaixanith ${ }^{1}$
}

\section{* Correspondence: \\ noysoukssly@yahoo.com \\ 1. Faculty of Education, National \\ University of Laos}

Received: 5 August 2020

Revision: 16 October 2020

Accepted: 4 December 2020

Published online: 20 March 2021

\begin{abstract}
This study is aimed at (1) examining the preferred English learning styles among secondary school students; (2) exploring the mismatches in teachers' English teaching styles and students' learning style preferences. A quantitative approach was used to seek answers to the research questions. The sample of this research involved 204 students and 5 teachers of English from 5 different secondary schools in Vientiane Capital, Lao PDR. All student and teacher participants were invited to rate their agreement levels on a five-point rating scale, towards Reid's (1995) six learning style preferences. The data collected were analyzed based on descriptive statistics. The findings reveal that student participants had more than one preferred learning styles. They preferred Kinesthetic, Group, and Audio learning styles in their English classes. For them, learning through doing, learning and working together with classmates, doing or resolving challenging tasks as well as listening to teachers and someone's instructions through interaction made them learn more effectively. The study also finds that mismatches in styles between teachers' teaching styles and students' learning style preferences do exist in four out of the five sampled schools. Teachers are more oriented to Visual styles. For instance, they favor writing things on board, asking students to read from textbooks, provide activities that make students read rather than listen to instructions, while students are likely not to prefer the Visual learning style.
\end{abstract}

Keywords: $\underline{\text { learning styles, }} \underline{\text { mismatches, }} \underline{\underline{\text { secondary schools, }}} \underline{\text { teaching styles }}$ 


\section{Introduction}

English has become an official language of ASEAN (Kirkpatrict, 2012). A primary priority for many nations that are internationalized is to develop English language skills among their citizens (Tien \& Cuong, 2015). English is the best among other languages people use to go online (Ananiadou, MacNaught, \& Thompson, 2012). It is also a language used in world-wide communications (Crystal, 2003). However, it is challenging for teachers in non-English speaking countries to perform teaching effectively. English teaching-learning process is claimed to have a huge barrier. For instance, students are demotivated to learn English and have negative attitudes towards English (Gathumbi, Bwire, \& Roy Campell, 2014; Khajloo, 2013; Lin \& Chien, 2010). However, the effectiveness of teaching and learning also relies on the teacher factor. For instance, the teaching capacities of teachers are fundamental for student learning progress. Walter and Briggs (2012) confirm that teacher's teaching quality affects students' learning success. Similarly, teachers would be able to notice the nature of learning by students, limit or problems in learning among them, and teacher could even know how to solve such problems to enhance their learning through planning and designing of teaching approaches consistent with students' needs (Vanstone et al., 2000). Therefore, knowing students' learning style preferences by teachers and matching teaching approaches and learning styles would increase the effectiveness of learning.

Several scholars or educational researchers have become interested in students' learning styles for decades. Learning style refers to an individual learner's methods of absorbing or receiving information in which they feel most comfortable to learn and learn effectively through (Oxford, 2003; Wintergerst \& DeCapua, 2001; Xu, 2011; Zywno $\&$ Waalen, 2002). All teachers will indeed encounter a diversity of students' learning styles in a single class (Dreyer \& Walt, 1996; Felder \& Brent, 2005; Montgomery \& Groat, 1998). People learn in different ways such as through seeing, hearing, doing, or being told (Prasonxay, 2006; Reid, 1987). Several scholars (Alkhatnai, 2011; Razawi, Muslim, Razali, Husin, \& Samad, 2011; Vaseghi, Ramezani, \& Gholami, 2012) agree that learning style determines success in learning among language learners. According to Zhou (2012), learning style indicates what approach students prefer to learn and how they learn something comfortably. Understanding learners' preferred learning styles contribute to teachers' teaching effectiveness, as teachers can understand strengths and weaknesses of students (Gilakjani, 2012; Montgomery \& Groat, 1998; Mulalic et al., 2009; Razawi, et al., 2011; Tai, 2013). Without knowing how students learn, it might lead to a mismatch in teaching and learning styles (Oxford, 2003), and this mismatch affects teacher-student relationships, student's confidence in learning, and attitudes towards a subject. Asba and colleagues (2014) found that mismatches in styles between teacher and students do exist in educational settings. In previous studies (Akbarzadeh \& Fatemipour, 2014; Asba et al., 2014; Fung, 2012; Ghada, Rima, Nola, \& Mona, 2011), the findings have proved that mismatches in styles between teachers and students occur. Most importantly, effective teachers have to be capable of analyzing preferred learning styles by students to adapt or change the way they teach and consider matching in teachers' teaching and students' learning styles (Gilakjani, 2012; Gokalp, 2013).

\subsection{Problem Statement}

Teaching-learning English as a foreign language (EFL) in a Lao EFL context has been suspicious in its quality, especially a prominent issue is concerned with English teaching of teachers at a secondary school-level (MoES, 2015). Buangern, Lasayphone, and Hiragawa (2008) have proved that secondary school teachers of English have several concerns with technical and teaching skills that are well-suitable for their students. Accordingly, a study conducted by Suriyavongsa (2013) revealed that most teachers were lacking a wide array of techniques of teaching. Another concern is that understanding students and motivating students to learn is complicated for Lao teachers' English teaching (Sengsouliya et al., 2015). As Montgomery and Groat (1998) mentioned, all teachers will encounter a diversity of students' learning styles in a single class. Unless teachers know different techniques and various teaching styles practices, it brings concerns to the effectiveness of teaching and learning (Dreyer \& Walt, 1996).

Even though hundreds of studies of learning style preferences exist, some limitations have been captured that there has been plenty of researches working on student learning style preference at college and university level. Identifying how secondary school students learn in English classes appears less conducted. According to the literature review, further research on the reality of matches or mismatches in styles between teachers and students is strongly recommended. However, some previous studies have not included multiple cases or collecting data from different schools. Sengsouliya et al. (2015) pointed out that there are a complex issue and instructional barriers to English teaching in secondary schools. The barriers involve the demotivation of learning English of students and the teachers cannot teach accordingly to learners' needs. Most importantly, an investigation on English learning styles preferred 
by Laotian learners of secondary schools has not yet widely conducted by local and international researchers. Besides, a few studies have investigated matches or mismatches in teacher teaching styles and students' learning styles preferences. Some previous studies have proved mismatches in styles between teachers and students in educational settings (Akbarzadeh \& Fatemipour, 2014; Asba et al., 2014; Fang, 2012; Ghada, Rima, Nola, \& Mona, 2011), however, the mismatches occurred with no serious means (Fang, 2012).

\subsection{Research Questions}

This study is guided by the following research questions:

- What are the students' preferred learning styles in English classes in secondary schools in Vientiane Capital, Lao PDR?

- What are the mismatches in teachers' teaching styles and students' learning style preferences in English classes in the sampled schools?

\subsection{Objectives of the Research}

This research aims to understand how Laotian students learn English at a secondary school-level and find out whether there are any mismatches in styles between teachers and students. Therefore, this quantitative study follows these objectives:

- To examine students' preferred learning style in English classes in secondary schools in Vientiane Capital, Lao PDR;

- To determine mismatches in teachers' teaching styles and students' learning style preferences in English classes in the sampled schools.

\section{Review of the Literature}

\subsection{Definitions of Learning Styles}

Learning style has been widely defined in different words by several researchers. For Zywno and Waalen (2002), learning style refers to "receiving and processing information within a learning environment" (p. 35). Similarly, Oxford (2003) defines learning styles as the general approaches -for example, global or analytic, auditory or visual that students use in acquiring a new language or in learning any other subject. Xu (2011) puts that "Learning style concerns with individual learners; learning style is the ways of learning; learning style is relatively consistent or stable for individual learners; learning style is the favored or preferred way of learning for an individual learner" (p. 413414). Another definition, written in a book (2012) called "Teaching and Learning Styles: VARK Strategies," Neil Fleiming defines learning style as "individuals' characteristics and preferred ways of gathering, organizing, and thinking about information” (p. 1).

More consistently, Barzegar and Tajalli (2013) define learning style as "a student's consistent way of responding to and using stimuli in the context of learning" (p. 2). According to Wintergerst and DeCapua (2001), it is viewed that learning styles refer to the ways a learner learns in which they feel like or happy with. While, Dunn, and Burke (2005) said "Learning styles are a combination of many biological and experientially imposed characteristics that contribute to concentration, each in its own way and all together as a unit. Learning style is more than merely whether a student remembers new and difficult information most easily by hearing, seeing, reading, writing, illustrating, verbalizing, or actively experiencing; perceptual strength is only one part of learning style" (p.1). To sum up, based on the abovementioned literature, the definitions of learning styles vary by different scholars. However, the one shared basic concept can be summarized that learning style is meant by an individual learner's method of absorbing or receiving information in which they feel most comfortable and learn effectively through. And it is characterized as stable.

\subsection{Key Concepts of Students' Learning Behaviors}

Dunn and Burke (2005) have presented some concepts in relation to how learners learn. For instance, it is natural that differences in learning styles exist among learners, even in the same family, each of them learns in different styles. And it is not true to say one learning style is better than others. That means some may learn best through hearing and being told. Others may prefer learning by doing often, as it is the only way they learn best. Dunn and Burke additionally view that young learners won't feel comfortable to learn in a controlling situation or under pressure. These learners tend to prefer learning with freedom, either with friends or on their own, but not with teachers' monitoring. Teachers 
should not treat all students as the same learner type. As Dunn and Burk (2005) state "most children are not auditory - it is rare for students to remember 75 percent of what is said to them in a typical class period - lectures, discussions, and questioning are the least-effective method of teaching" (p. 6). However, many researchers claimed that individual learner may have more than one preferred learning style.

For instance, Donkoh et al. (2015) found that majority of students in their study were classified as a combination of auditory and visual learners, meaning that they learn best through hearing and seeing. Students know themselves as well as the ways how they learn better. And they may have reasons for their choices of learning styles. Having more preference for a particular learning style than the others by students has its own reasons, and that has been influenced by different factors, for example, an individual factor. A study conducted by Liu (2012) proved such an idea. Through a mixed-method approach, Liu found that majority of students preferred learning alone. And such a learning style choice has been found that students expected and cared much about passing an exam and achieving their learning goal. For this reason, they did not go for a group learning style, they preferred learning hard individually instead.

\subsection{Significance of Understanding Learners' Learning Style Preferences}

Learning style has been of interest by several educational researchers due to its influence on educational dimensions. Learning style serves as an influential role in learning settings (Alkhatanai, 2011; Lee, 2010). Similarly, learning style indicates what students prefer to learn and how they learn something comfortably (Zhou, 2012). It is also claimed that learning style determines success in learning among language learners (Razawi et al., 2011; Vaseghi et al., 2012). Researchers, educators, and instructors have considered identifying how students learn very critically. For Reid (1995) and Jhaish (2010), understanding in depth of how students learn "will enable students to take control of their learning and to maximize their potential for learning" (p. 14). According to Montgomery and Groat (1998), recognizing learners' diverse learning styles is critical to the development of teaching effectiveness.

While, many others contend that by knowing students' preferred learning styles teachers can help students learn better and achieve the educational purposes (Gilakjani, 2012; Mulalic et al., 2009; Razawi, et al., 2011; Tai, 2013), for instance, it can make teachers understand strength and weaknesses of students. Also, being knowledgeable of students makes teachers visualize their students' learning nature or their diverse learning patterns, which is supportive of teachers' teaching practice and planning. In contrast, if teachers fail to analyze or not to recognize students' diversity in learning styles mismatch in teaching and learning styles is most likely to occur. Seemingly, Oxford (2003) supports the view, if the teaching and learning styles are not matched; students are to be less confident and increasingly worried. This eventually would destroy the teacher-student relationships and the attitudes towards the subject.

In a classroom diversity in learners would exist. It is, therefore, inevitable for teachers to encounter their diverse learning style preferences (Dreyer \& Walt, 1996; Felder \& Brent, 2005; Montgomery \& Groat, 1998). This seems to be true because learning can happen in different ways; it depends on individual preference, for instance, some persons would be more comfortable learning through data, while others might be in favor of learning through models and theories (Vaseghi et al., 2012). To address such a mismatch in teachers' and students' styles, several researchers (Dreyer \& Walt, 1996; Jhaish, 2010; Mulalic, et al., 2009; Reid, 1987; Vaseghi et al., 2012; Wang, 2012; Zhou, 2012) agree that teachers should share their responsibilities. For instance, Jhaish (2010) recommends that it is a responsibility for teachers to be caring for what students need and how they learn. Simply put, understanding students' learning patterns is the first thing for teachers to care about prior to selecting a teaching tool and/or materials in use.

An effective teacher should be able to teach that corresponds to what learners need and matches how learners learn. If teaching methods can be adapted to correspond to how students learn, it can help improve students' learning achievement, attitudes towards teachers, and motivation for study (Gilakjani, 2012; Gokalp, 2013). What Dreyer and Walt (1996) put seems to be true, that "A lecturer who creates a truly "learner-centered" classroom understands and respects the diversity of learning strengths within any group, and offers choices in how information and skills will be acquired" (p. 480). Furthermore, students should be taught about diverse learning styles for helping them choose the best learning style for themselves. Together with this, teachers should also provide an opportunity for students to assess their preferred learning modes (Gokalp, 2013; Reid, 1987; Vaseghi et al., 2012).

\subsection{Mismatches in Teacher Teaching and Student Learning Styles}

Knowing the definitions of teaching style is significant in determining matches or mismatches in styles between teachers and students. According to Grasha (2002), teaching style is defined as a teacher's behavioral exposure that is enduring and consistent (Asba et al., 2014). Yoshida and colleagues (2014) cite Conti's (2004) statement, saying that 
"Teaching style refers to the distinct qualities displayed by a teacher that are persistent from situation to situation regardless of the content" (p. 76-77). A concept of teaching style has become much interest by educational researchers for decades, and this concept is needed for teachers to perform their teaching profession, that teachers need to understand clearly and care about it (Yoshida et al., 2014).

Accordingly, Gilakjani (2012) puts that teachers basically have their philosophy of education and unique belief and methods in terms of interacting with students, designing lesson plans, selecting contents for their teaching, as well as choices of assessing their student learning outcomes. Gilakjani further adds that teachers also have their teaching style preferences that they use throughout their lessons, believing that such styles may make their students understand lessons better or may enhance students' learning progress. Reid (1987) mentions that all individual students have their own learning styles. That means students may learn well in different ways. Several authors (Dreyer \& Walt, 1996; Felder \& Brent, 2005; Montgomery \& Groat, 1998) agree that it is inevitable for teachers to encounter a classroom of diverse learners who have diverse learning style preferences.

Through reviewing a wide range of literature, Asba and colleagues (2014) found that mismatches in styles between teacher and students do exist in educational settings. In previous studies (Akbarzadeh \& Fatemipour, 2014; Asba et al., 2014; Fang, 2012; Ghada, Rima, Nola, \& Mona, 2011; Karabuga, 2015; Shim \& Shur, 2018), the findings have proved that mismatches in styles between teachers and students occur. For instance, Fang (2012) explored whether or not mismatches exist in teacher's teaching styles and students' learning styles in China. The sample includes 157 students from college second year-level and 4 teachers, aging between 26-42 years old. The results revealed that out of the total 13 dimensions of learning styles, independent learning style is scored the highest, meaning that the student participants expressed their preferences on independent learning. In terms of mismatches, the study found some mismatches in styles between instructors and learners. However, the mismatches occurred with no serious means, which is the same as the work of Karabuga (2015).

Even more, Akbarzadeh and Fatemipour (2014) investigated matches and mismatches between students' learning styles and teachers' teaching styles preferences in Iran. The study showed that students rated their preferred learning style on Tactile. However, Tactile was found to be a teachers' negligible teaching style preference. From questionnaires, teachers rated that they know about the theories of learning styles, but they don't apply them in their classrooms. From observation, teachers showed they don't teach correspondingly to students' learning styles. The interview data pointed out that teachers explained they have stable teaching styles that are based on the characteristics of the course they teach, not based on students' learning style preferences.

Ghada, Rima, Nola, and Mona (2011) explored the learning styles of English learners at a university level in Lebanon, and further analyze if there is a match or mismatch in the teaching styles of teachers and learning styles of students. The participants in this study consist of 103 students and 5 teachers. The study showed that Lebanese students had more than one learning styles, they consider themselves as auditory, kinesthetic, tactile, and visual learners. The study also pointed out that there are some mismatches in teaching and learning styles. According to the findings, the individual style was preferred by all teacher participants, whereas this individual learning mode was not preferred by all most $50 \%$ of students. Moreover, almost $90 \%$ of the student participants exhibited their more preference for audio learning style, whereas only $60 \%$ of the teacher sample expressed their favor of this style.

Another case study, conducted in Yemen by Asba and colleagues (2014), looked at mismatches in teaching and learning styles. The study had 179 students as the sample, through the use of a questionnaire survey and the other 50 teachers as the teacher sample, collecting data through observation and videotaping. The study revealed that the student sample preferred kinesthetic and tactile learning styles while teachers are found to have a preference towards auditory and visual teaching modes of teaching. Similarly, Shim and Shur (2018) explain mismatches can happen as the perspectives on how to learn between learners' and their teacher are generally different. Teachers' great efforts on matching their teaching styles with students' preferred learning styles would be ideal. According to Stebbins (1995), matching the styles of both teacher and students could improve students' motivation, behaviors, and the whole attitudes towards their learning. On the other hand, if their styles are not matched, the mismatch occurred could affect negatively students' learning process (as cited in Ghada et al., 2011).

More authors (Akbarzadeh \& Fatemipour, 2014; Awla, 2014) have a similar view on this matter, that paying attention by teachers on students' learning styles and having consideration of matching teaching approaches and student learning modes would create a positive learning environment for students. Most importantly, students will have a joyful, faster, and more effective learning process when they can learn in ways they feel most comfortable to learn 
and they are taught consistently with their current learning modes. So, teachers must understand students' weaknesses and strengths of learning and then consider using or applying multiple teaching approaches based on students' learning situations (Peacock, 2001).

\subsection{Conceptual Framework for the Study}

Having reviewed a wide literature, several researchers have accepted that the scale, developed by Reid's (1995), is considered a very well-developed, high reliability, and very consistent instrument to use in exploring learning styles among EFL learners. However, from reading past studies, the present authors have noticed that identifying students' learning styles preferences at a secondary school-level is quite less conducted. Together with this, there remain a few pieces of research on matches or mismatches in styles between teachers and students (see the figure that follows).

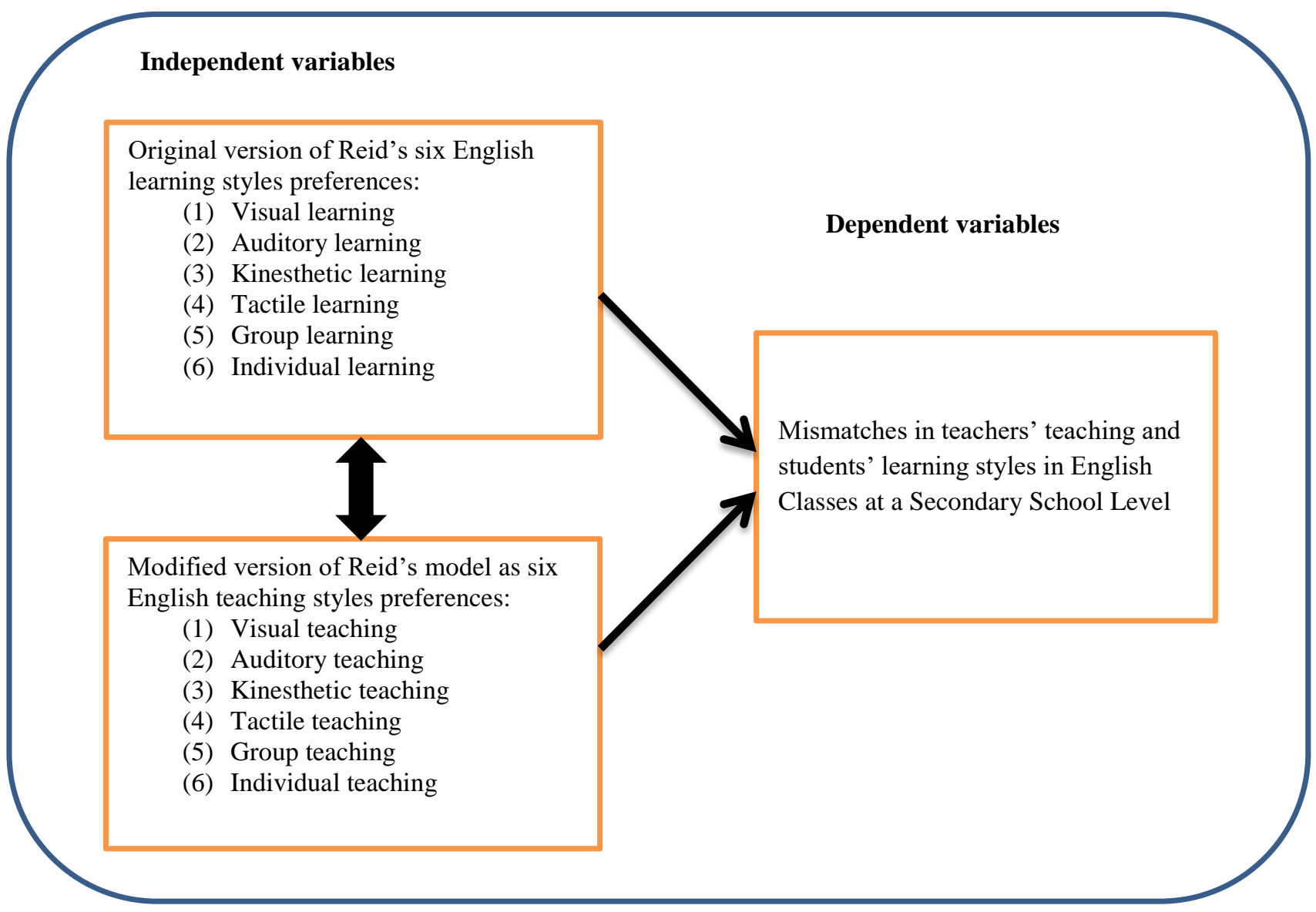

Figure 1. A Framework demonstrating the conceptualization of the study

Therefore, in the present study, the authors aim at investigating secondary school students' preferred English learning styles and capturing mismatches in teacher teaching styles and students' learning styles. This study is designed to employ Reid's model (1995), the PLSPQ questionnaire survey is used as the main instrument in collecting data. That includes the data collection of teachers' styles to capture mismatches a modified version of the same instrument is used. The six modes of learning styles developed by Reid involve Auditory, Visual, Kinesthetic, tactile, Group, and Individual learning styles. The conceptual framework for the study is demonstrated in a form of a chart (See the figure shown above).

\section{Methodology}

\subsection{Research Design}


This research employs a quantitative method approach to understand mismatches in teachers' English teaching style and students' English learning style preferences in the case study of Laotian secondary schools. According to Dawson (2002), quantitative research requires big data. That means the data to be collected has to be a big scale survey, as it deals more with statistics. Accordingly, Creswell (2012) puts that "In quantitative research, the investigator relies on statistical analysis (mathematical analysis) of the data, which is typically in numeric form. Creswell further indicates that the uniqueness of quantitative research involves being able to explain research problems with numeric trends and the relationship of variables. In this research, the aims are meant to look at what learning styles students are likely to prefer to use in their English learning and which styles teachers are oriented to employ in their English teaching performance, in the context of Lao secondary schools. The study is based on five cases or five randomly selected schools in Vientiane Capital, Lao PDR. So, it is a better choice for that the present authors selected this research type in exploring the said mismatches in student learning style and teacher teaching style preferences, with expecting to get big-scale data in describing or explaining the mismatches in numeric trends. Similarly, several past researches (Abante et al., 2014; Donkoh et al., 2015; Khanum, 2014; Shuib \& Azizan, 2015) have employed quantitative-type research in their investigations of student learning style preferences. They agree that this method is easily administered and convenient for the invited sample to do self-reporting of which styles represent best to them.

\subsection{Participants}

In this study, the present authors selected five schools by taking a simple random sampling method. The five schools selected were Tanmixay secondary school, Donnoun secondary school, Thongmang secondary school, Tha-Ngon secondary school, and Non-Sa-Ath secondary school. Once the sampled schools were determined, the $12^{\text {th }}$ grade students from the top class (7/1 classes) from each of the five sampled schools were invited to answer the questionnaire. For the teacher sample, five teachers who teach English in these top classes were also the participants, giving responses to the questionnaire. The total number of student and teacher participants from five schools included 204 students and 5 teachers of English. The detail of student and teacher sample for this research is shown in the following table.

Table 1. The number of student and teacher participants in five schools

\begin{tabular}{llcc}
\hline No. & School Names & $\begin{array}{c}\text { No. of Students } \\
\left(12^{\text {th }} \text { grade, from } 7 / 1 \text { class }\right)\end{array}$ & $\begin{array}{c}\text { No. of Teacher } \\
\text { (who teaches English in } 7 / 1 \\
\text { class })\end{array}$ \\
\hline 1. & Tanmixay secondary school & 49 & 1 \\
2. & Donnoun secondary school & 39 & 1 \\
3. & Thongmang secondary school & 47 & 1 \\
4. & Tha-Ngon secondary school & 36 & 1 \\
5. & Non-Sa-Ath secondary school & 33 & 5 \\
& Total sample $=$ & 204 & \\
\hline
\end{tabular}

\subsection{Instrument}

This research employed a Perceptual Learning Style Preferences Questionnaire (PLSPQ), developed by Reid (1995), in collecting data. Reid's PLSPQ has six dimensions of perceptual learning styles such as Visual, Audio, Kinesthetic, Tactile, Individual, and Group learning style preferences. This instrument has 30 items across the six dimensions (5 statements in each style), asking participants to do a self-reporting on their preferred styles. In this questionnaire, Reid classified the six learning styles into three types such as Major, Minor, and Negligible. Major is meant by the most preferred style, learners learn well through it; Minor refers to one that learners can still learn, but not that well, and Negligible is a style in which learners have difficulty to learn. Student participants were invited to rate their agreement level, ranging from (1) Strongly Disagree, (2) Disagree, (3) Moderate, (4) Agree, and (5) Strongly Agree. This 
questionnaire survey has been widely accepted as a quality instrument in investigating student learning style preferences.

Several researchers (Alkhatnai, 2011; Barzegar \& Tajalli, 2013; Karthigeyan \& Nirmala, 2013; Khanum, 2014; Peacock, 2001; Tai, 2013; Tuan, 2011; Wang, 2012) also used this instrument in their works. For instance, Peacock (2001) also used this instrument in his study of mismatches in styles between teachers and students in Hongkong. He measured students' learning style preference using the original version, and a modified version of the same instrument in measuring teachers' teaching style preferences. Furthermore, Dreyer and Walt (1996) also recommend that Reid's survey is one of the highly reliable and valid instruments that teachers can consider using it in relevant research. In this regard, teachers were invited to rate their frequency of practices in using styles in their English teaching such as (1) Never, (2) Seldom, (3) Sometimes, (4) Usually, and (5) Always, based on the modified version of Reid's survey. The original version of the questionnaire survey, developed by Reid (1995), was translated into Lao and used the Laotranslated version in collecting data. However, before that, the instrument was brought to two experts to check its content and the wordings. Through checking, there were a few changes due to unclear wordings. Then the present authors conducted some try-out of the instrument and an analysis of Cronbach's Alpha to check about the reliability value. The result showed that the reliability value was at 0.85 .

\subsection{Data Collection}

The research collected quantitative data through distributing a questionnaire survey to both student and teacher sample/participants. 204 students from five classes were asked to rate their preferred English learning styles, while 5 teachers who taught these classes were invited to rate their frequency of practices in using styles in their English teaching such as (1) Never, (2) Seldom, (3) Sometimes, (4) Usually, and (5) Always.

\subsection{Data Analysis and Interpretation}

Descriptive statistics were employed in this quantitative-method approach. The data collected were analyzed for frequency, percentage, mean, and standard deviation. The conduct was run with a computer program. The description of the results of investigating on mismatches in student learning styles and teacher teaching styles was based on the participants' rating on a 5-point rating scale. The interpretation method for determining students' English learning style preferences is based on Reid's (1995) guide, that the student participants' rating of their agreement level is converted into numbers. Then the numbers are added up, the total value is then multiplied by 2 . The result numbers are used to compare each type of learning style such as Major Learning Style Preference, the values are between (3850); Minor Learning Style Preference (25-37); and Negligible (0-24). For the interpretation of mismatches in teacher teaching style and student learning style, the rating values by teachers are also conducted with adding up. Then the total is then multiplied by 2 . The mismatches are based on the value differences and/or the top two rankings from both sides (teacher style ranking and student style ranking).

\section{Findings}

\subsection{Participants' Characteristics}

Out of the total number of 204 student participants, 82 students or about $40.2 \%$ are males, and the other 119 students are females, that make up 58.3\%. Concerning to whether or not they are currently taking extra English classes, there are 50 students, who are currently taking extra English classes, accounting for $24.5 \%$, while the other 144 are those students who are not, which make up 70.6\%. Besides, within the total number of 204 student participants, 112 students expressed much understanding towards their teachers' English teaching, which covers 54.9\%, and the other 81 are those students who held at a moderate level of understanding, which make up $39.7 \%$. Another 8 students or $3.9 \%$ of the sample expressed little understanding of it.

\subsection{Participants' Preferred English Learning Styles}

According to the Table 2 below, it is indicated that the participants had learning styles as their major learning style preferences, which include Kinesthetic $(M=39.46)$, Group $(M=39.36)$, and Audio ( $M=38.24)$, respectively. That means the participants expressed that they learn well and feel most comfortable to learn English through such three learning styles. On the other hand, the participants rated the other three learning styles as their minor English learning style preferences, which include Tactile $(M=36.72)$, Visual $(M=31.90)$, and Individual $(M=28.82)$, respectively. That means they are likely to express that they feel a little comfortable learning English through the three learning styles. 
The above-mentioned description would be well-confirmed with the rating on single items of each learning style. Participants agree that they enjoy learning in class by doing, they learn best in class when they can participate in related activities. Moreover, they get more work done when they work with others, they accept that they learn more when they study with a group, and they learn things better in class when their teachers give instruction and when they listen to someone.

Table 2. The participants' preferred learning styles

\begin{tabular}{lcc}
\hline \multicolumn{1}{c}{ Learning Styles } & Mean & Type \\
\hline Kinesthetic & 39.46 & Major \\
Group & 39.36 & Major \\
Audio & 38.24 & Major \\
Tactile & 36.72 & Minor \\
Visual & 31.90 & Minor \\
Individual & 28.82 & Minor \\
\hline
\end{tabular}

Notes: Major Learning Style Preference

38-50; Minor Learning Style Preference 25-37;

Negligible 0-24

\subsection{Mismatches in Teacher's Teaching Styles and Student's Learning Styles Preferences}

This section presents the overall teacher's teaching style preferences from 5 teachers of English in 5 different secondary schools, namely Tanmixay Secondary School (C1), Donnoun Secondary School (C2), Thongmang Secondary School (C3), Tha-Ngon Secondary School (C4), and Non-Sa-Ath Secondary School (C5). The present authors employed the same criteria of determining student's learning style preferences in deciding which teaching style teachers are oriented to. Teacher participants were invited to rate their agreement level based on the modified Reid's model of six styles such as Visual, Audio, Kinesthetic, Tactile, Individual, and Group teaching styles. The mean scores of all single items in each style are added up then they are multiplied by 2 . The mismatches in teacher and student styles are measured or determined by the differences in values (on top 2-ranking), rated by students and the teacher who teaches English to them. This analysis is conducted separately on a basis of school by school (from the 5 schools).

Table 3. The overall teacher's teaching style preferences

\begin{tabular}{llllll}
\hline Teaching Styles & C1 & C2 & C3 & C4 & C5 \\
\hline Visual & 46 & 48 & 40 & 42 & 46 \\
Audio & 46 & 40 & 44 & 46 & 44 \\
Kinesthetic & 38 & 42 & 46 & 44 & 48 \\
Tactile & 50 & 42 & 44 & 36 & 46 \\
Individual & 36 & 42 & 38 & 32 & 44 \\
Group & 40 & 48 & 44 & 42 & 42 \\
\hline
\end{tabular}

\subsubsection{Mismatches in School One (C1)}

According to Table 4, the statistical analysis shows that students in School One rated their most preferred English learning styles to kinesthetic $(M=40.40)$, and Group learning style $(M=40.32)$, whereas the teacher was oriented to Tactile $(M=50)$, and Visual-Audio teaching styles $(M=46)$. It can be said that there are a few mismatches in styles 
between students and the teacher, that the teacher ranked Tactile the first most preference, while students ranked Kinesthetic the first most preference. However, the present authors do not consider this style difference (Kinesthetic VS Tactile) as a serious mismatch because both styles require student physical involvement in classroom-related activities. So, the only one seemed-to-be mismatch between them in this school was their second most preferred styles. For instance, the teacher preferred Visual as the second most preferred teaching style, while students were likely not to employ much of this learning choice; they went for Group as their second learning preference.

Table 4. The comparison of students' English learning styles and their English teacher's teaching style preference of School One

\begin{tabular}{cccc}
\hline \multicolumn{2}{c}{ Student Styles } & \multicolumn{2}{c}{ Teacher Styles } \\
\hline Preference Ranking & Mean & Preference Ranking & Mean \\
Kinesthetic & 40.40 & Tactile & 50 \\
Group & 40.32 & Visual & 46 \\
Audio & 39.30 & Audio & 46 \\
Tactile & 37.82 & Group & 40 \\
Visual & 31.90 & Kinesthetic & 38 \\
Individual & 29.26 & Individual & 36 \\
\hline
\end{tabular}

\subsubsection{Mismatches in School Two (C2)}

According to Table 5, the statistical analysis shows that students in School Two rated their most preferred English learning styles to Group $(M=39.22)$, and kinesthetic learning style $(M=37.52)$, whereas the teacher was oriented to Group (M=48), and Visual teaching style ( $=48)$. Even though, both the teacher and students ranked Group the same as their most preferred style, a few mismatches in styles between them were found that the teacher preferred Visual style in English teaching performance as the second most preferred, while students were likely not to employ much of Visual learning style; they preferred Kinesthetic as their second choice of learning.

Table 5. The comparison of students' English learning styles and their English teacher's teaching style preference of School Two

\begin{tabular}{cccc}
\hline \multicolumn{2}{c}{ Student Styles } & & \multicolumn{2}{c}{ Teacher Styles } \\
\hline Preference Ranking & Mean & Preference Ranking & Mean \\
Group & 39.22 & Group & 48 \\
Kinesthetic & 37.52 & Visual & 48 \\
Audio & 37.22 & Kinesthetic & 42 \\
Tactile & 35.42 & Tactile & 42 \\
Visual & 30.60 & Individual & 42 \\
Individual & 27.48 & Audio & 40 \\
\hline
\end{tabular}

\subsubsection{Mismatches in School Three (C3)}


According to Table 6, the statistical analysis shows that students in School Three rated their most preferred English learning styles to Kinesthetic $(\mathrm{M}=41.90)$, and Group learning style $(\mathrm{M}=40.42)$, while the teacher was also oriented to Kinesthetic $(M=46)$, and Group teaching style $(M=44)$. When looking closer at all styles in the ranking of both the teacher and students, it is found that there was not any mismatch in styles between them. That means the teacher and students ranked all styles the same, or simply put, they were likely to employ almost the same styles in their teaching and learning English.

Table 6. The comparison of students' English learning styles and their English teacher's teaching style preference of School Three

\begin{tabular}{cccc}
\hline \multicolumn{2}{c}{ Student Styles } & \multicolumn{2}{c}{ Teacher Styles } \\
\hline Preference Ranking & Mean & Preference Ranking & Mean \\
Kinesthetic & 41.90 & Kinesthetic & 46 \\
Group & 40.42 & Group & 44 \\
Audio & 39.70 & Audio & 44 \\
Tactile & 39.06 & Tactile & 44 \\
Visual & 32.20 & Visual & 40 \\
Individual & 29.70 & Individual & 38 \\
\hline
\end{tabular}

\subsubsection{Mismatches in School Four (C4)}

According to Table 7, the statistical analysis shows that students in School Four rated their most preferred English learning styles to Audio ( $M=37.26)$, and Group learning style $(M=37.10)$, while the teacher was oriented to Audio $(\mathrm{M}=46)$, and Kinesthetic teaching style $(\mathrm{M}=44)$. When looking closer at all styles in the ranking of both the teacher and students, the only one seemed-to-be mismatch in styles between them was that the teacher was more likely to prefer Visual, whereas students were likely not to.

Table 7. The comparison of students' English learning styles and their English teacher's teaching style preference of School Four

\begin{tabular}{cccc}
\hline \multicolumn{2}{c}{ Student Styles } & \multicolumn{2}{c}{ Teacher Styles } \\
\hline Preference Ranking & Mean & Preference Ranking & Mean \\
Audio & 37.26 & Audio & 46 \\
Group & 37.10 & Kinesthetic & 44 \\
Kinesthetic & 36.94 & Visual & 42 \\
Tactile & 34.54 & Group & 42 \\
Visual & 31.22 & Tactile & 36 \\
Individual & 29.76 & Individual & 32 \\
\hline
\end{tabular}

\subsubsection{Mismatches in School Five (C5)}

According to Table 8, the statistical analysis shows that students in School Five rated their most preferred English learning styles to Kinesthetic ( $M=39.56)$, and Group learning style $(M=39.02)$, whereas the teacher was oriented to Kinesthetic ( $M=48)$, and Visual teaching style $(M=46)$. Even though, both the teacher and students ranked Kinesthetic the same as their most preferred style, a few mismatches in styles between them remained to be found that the teacher 
preferred Visual style in English teaching performance as the second most preferred, while students were likely not to employ much of Visual learning style. Students were more likely to prefer Group learning styles. On the other hand, the teacher expressed little preference for group teaching style.

Table 8. The comparison of students' English learning styles and their English teacher's teaching style preference of School Five

\begin{tabular}{cccc}
\hline \multicolumn{2}{c}{ Student Styles } & & \multicolumn{2}{c}{ Teacher Styles } \\
\hline Preference Ranking & Mean & Preference Ranking & Mean \\
Kinesthetic & 39.56 & Kinesthetic & 48 \\
Group & 39.02 & Visual & 46 \\
Audio & 36.84 & Tactile & 46 \\
Tactile & 35.62 & Audio & 44 \\
Visual & 33.68 & Individual & 44 \\
Individual & 27.50 & Group & 42
\end{tabular}

\section{Discussion}

As stated earlier, this quantitative research is conducted to increase the understanding of students' learning styles preferences and mismatches between teachers' teaching styles and students' learning styles preferences in English in Lao secondary schools. The present researchers found different interesting findings which are brought to a discussion with existing literature as follows:

Secondary school students have multiple learning style preferences in English classes: In the present study, the findings indicate that the student participants, who are $12^{\text {th }}$ grade in secondary schools, are likely to prefer more than one learning style in their English classes. Their preferred learning styles include Kinesthetic learning, Group learning, and Audio learning styles. This trend seems to be consistent with Ababneh (2015), Donkoh et al. (2015), and Ghada et al. (2011) who found that their sample favored several learning styles. Seemingly, the trend supports the view proposed by Dreyer and Walt (1996), stating that a variety of learning styles do exist among adult learners because the sample of the present study is in the final year to complete a high school and then they will transit to colleges and universities.

Kinesthetic, Group and Audio learning are perceived as the most preferred learning styles among the student sample. As it was presented in the above paragraph, the participants learn best through these three styles such as Kinesthetic, Group, and Audio learning modes. Some previous studies, for instance, Barzegar and Tajalli (2013), Khmakhien (2012) found the same result, their sample students rated Kinesthetic and Group as their major learning style preferences. Similarly, Razawi, Muslim, Razali, Husin, and Samad (2011) investigated 90 students in the Malaysian context. Razawi and colleagues found that visual and group are the most favored learning styles by the sample. Peacock (2001) found that the student participants expressed their preference for Kinesthetic and Audio learning styles. Furthermore, the present study seems to contribute to that of Rossi-Le's (1989) research, who explored the English learning style choices among 147 students from different countries such as China, Laos, Vietnam, Spain, and others. Rossi-Le pointed out that Laotian was one of the other groups who were in favor of the kinesthetic learning style.

The trend could be true according to recent research on factors influencing secondary school students, conducted by Sengsouliya and colleagues (2020), who found that peers or classmates strongly influence their learning engagement; learning with peers makes them learn more through sharing and have more critical thinking. Peer was also found to be the participants' good partner in English learning, just in case of having difficulties in understanding lessons. As they claimed, they consider their peers necessary for their learning, especially in time of preparing for an exam (Sengsouliya et al., 2019). They preferred to discuss with friends, through discussion they learn better. This seems to 
be relevant to the work done by Ramayah, Nasrijal, Leong, Sivanandan, and Letchumanan (2011), finding that peer was a strong determinant of Visual and Aural learning styles choices of students. And Liu's work (2012) showed that students' learning styles are developed through socialization with peers.

On the other hand, this research has shown that visual and individual learning are the least favored learning styles by the participants. This trend is similar to a work done by Peacock (2001) who found that the student participants disfavored Individual learning styles. Tai (2013) has shown that these two styles (Visual and Individual) were perceived as the least preferred learning styles among Taiwanese students. However, the present study has some conflicts with some other past studies. For instance, a research of Wintergerst's and DeCapua's work (2001), conducting oral interviews with 13 participants, showed that the informants went for the visual learning style over the others. Gilakjani (2012) also found the same. Also, more works that found a consistent finding include the one by Liu (2012) and another one by Tuan (2011), that individual learning was perceived as the most preferred learning style.

Mismatches in teachers' teaching and students' learning style preferences do exist. According to the results, mismatches occur across four out of the five sampled schools. The teachers are more likely to prefer visual style in their English teaching performance. However, visual learning is likely not to be the student sample' first or even not the second most preferred English learning style. They favor kinesthetic learning instead, for instance, they have fun with learning by doing; they also learn better through experimenting and doing things. Having reflected the student participants' rating in the first part of the questionnaire (participants' characteristics), it indicates that almost $40 \%$ of the total students exhibited little to moderate level of understanding towards their teachers' English teaching performance. This trend might be very true, as it is reported in a report of the Lao Ministry of Education and Sports (MoEs, 2015), secondary school teachers have limited knowledge of ICT. That means they cannot utilize technologies too much, including other audio aids in their teaching. So, most teachers are more likely to use traditional modes of teaching, for instance, writing lessons on the board, asking students to read things on the board or read on the textbooks, as well as providing reading-related activities rather than listening to instructions.

Moreover, this finding may support to the previous research of Thongma (2013) and Buangern and colleagues (2008), finding that Lao teachers of English in secondary schools lack various instructional techniques, and teachers cannot understand the learning characteristics among students, that includes lacking applying a suitable teaching approach to students (Sengsouliya et al., 2015). The present study has found the same result as of past researches (Akbarzadeh \& Fatemipour, 2014; Asba, 2014; Fang, 2012; Ghada, Rima, Nola, \& Mona, 2011; Karabuga, 2015; Peacock, 2001; Shim \& Shur, 2018), indicating that mismatches do exist in English teaching-learning process. The present study found that teachers are likely to have a preference towards visual teaching style, which is well consistent with that of Asba (2014). For the mismatch issue, there could be two reasons for it. One, teachers would not prefer to adapt their teaching styles accordingly to students' learning style preferences in their English classes due to their respect given to the curriculum, that teachers tend to teach according to the characteristics of the course (Akbarzadeh \& Fatemipour, 2014). Two, the mismatches may be caused by different attitudes, traditional beliefs, and past learning experiences of teachers (Akbarzadeh \& Fatemipour, 2014; Dreyer \& Walt, 1996; Shim \& Shur, 2018). That means teachers are likely to employ the styles which they learned best through in their learning experiences.

Through the present study, only one out of the five sampled schools did not appear any mismatches. A reason would be concerned with the teacher-student relationship. According to Khmakhien (2012), students' preferred learning styles can be changeable due to teachers' teaching performances. Furthermore, it was also found by Sengsouliya and colleagues (2019), that majority of students preferred to learn with teachers who are friendly (not too serious) and be interactive with students because they feel more comfortable to ask questions or discuss issues with teachers when they have concerns or difficulties. Guvenc (2015) put a similar view that if students can feel that their teachers pay great care to them, they become very happy and curious to participate in any activities teachers assign or conduct. Accordingly, Reyes et al. (2012) and Zepke, Leach, and Butler (2010) confirm that teacher-student relationships have a powerful influence on students' learning.

\section{Conclusion}

The results indicate that similar mismatches happen across the four schools, that the teachers are more likely to prefer Visual style in their English teaching performance, for instance they like to write things on board, asking students to read from textbooks, provide activities that make students read rather than listen to instructions, etc. For students, Visual learning style is likely not to be their first or second most preferred English learning style, confirmed by students from these four schools. On the other hand, the results reveal that there is no mismatch in styles between 
teachers and students in School Three (C3). That means the teacher and students ranked all the styles the same. Simply put, they are likely to employ almost the same styles in their teaching and learning English. For instance, the teacher is likely to teach English with kinesthetic style, through encouraging students to learn by doing, providing role-play activities in classrooms; and having all students participate in activities. In the meanwhile, students are happy and have fun with such teaching styles; they also rate to that they learn better through experimenting and doing things.

\subsection{Limitations of the Study}

In this study, some limitations can be summarized as follows:

Firstly, the data analyzed in this study were dependent on a single method, collecting data through the distribution of questionnaire surveys only. More views or opinions of participants were missing from the interpretation. Secondly, the study collected data only from the 12th grade students and from secondary schools within one district. The findings may not generalize the situations to different grades of a student and other schools. Thirdly, the mismatches of this study were based on value differences and ranking of preferred styles. A correlational statistic should be included in the analyzing the process, so that the findings are more realistic.

\subsection{Pedagogical Implications}

According to the findings of this study, the present researchers have outlined some suggestions for pedagogical practices as follows: Firstly, it is surprising to see that secondary school students have a preference towards multiple styles such as kinesthetic, Group, and Audio learning styles in English classes. Even though this is a case study of secondary schools in Vientiane Capital in Lao PDR, all teachers of English, who are in other schools such as in neighbor districts or schools in different districts where there are some similarities in levels, grades, and contexts, are recommended to recognize such learners' diverse learning styles. This is very important for all teachers to consider switching or shifting their teaching modes according to learners' learning situations for effective learning for them.

Besides, teachers need to do some preliminary investigations to seek insights into and understand how students learn; at least once before each academic year commencement; and it doesn't need to be large-scale. It can be a survey for their classes only. Through this method, teachers will have a sense of the learning culture of their students. At the same time, students will be able to know their own learning style preferences. By knowing their own learning modes, it will be easier for them to learn with plans. Most importantly, this could avoid mismatches in styles between teachers' teaching and student's learning style preferences. Teachers should be aware that if students do not feel happy or not joyful in learning with how teachers teach they then become bored and lead to having negative attitudes towards teachers, the subject, as well as the whole learning process.

Secondly, it is a good idea for teachers to treat all students equally and fairly. Being interactive with students as well as showing good rapport with them leads to effective learning among students. In the literature review, many scholars have proposed that teacher is a strong determinant for students' learning. That means if teachers give great care to students, they become happy and tend to fully participate in class activities provided. In this sense, providing any consistent classroom activities work well with students in English classes. As it is confirmed by this present study, students prefer to learn by doing. So, teachers are recommended to integrate more tasks or worksheets, assignments, and other group works where students could have challenges, as well as fun in learning. Through this kind of activity, they can also have opportunities to learn together with classmates, share things, and solve problems together in a group. Teachers should be aware that giving lectures does not work all the time. Teachers need to plan carefully when they should lecture and when they should not.

Thirdly, it is currently a technological age, teachers should be able to utilize technology in their teaching practices. This means teachers should make their lesson plans more interesting and meaningful to learners. Even more, teachers should also learn what types of technology devices or channels their students are in trend with and try to have them used for academic purposes. For instance, most students may use their smartphones for Facebook or chatting, then try asking them to use that channel as a class notice or for submitting assignments. It is clear that technology has a strong influence on students' learning effectiveness. The concerned school should consider this for improving their technology for education. For instance, having the internet installed in all classes facilitates their learning. Investing to make technology-friendly instructions is not wasteful. Fourth, promoting students to learn more effectively or meeting students' needs should be a shared task. Only teachers are not enough to deal with all learning issues among students. Other parties such as educators, policymakers, as well as curriculum planners should work together because it takes a long process. 


\section{Acknowledgments}

This work has been fully granted by the Korea Foundation for Advanced Studies (KFAS), through the Asia Research Centre of the National University of Laos. High appreciation is extended to the leadership of the Faculty of Education (FED) who facilitates and gives encouragement all the way. Another special thanks also go to the research team: Assoc. Prof. Dr. Sithane SOUKHAVONG, Dr. Say PHONEKEO, Souk SENSOULIYA, MA., and Toby XAIXANITH, MA. for their commitments on giving invaluable and helpful advice for the completion of this study.

\section{References}

Ababneh, S. (2015). Learning styles and preferences of JordaÂ $\neg$ nian EFL graduate. Journal of Education and Practice, 6(15), 31-37.

Abante, M. E., Almendral, B. C., Manansala, J. E., \& Mañibo, J. (2014). Learning styles and factors affecting the learning of general engineering students. International Journal of Academic Research in Progressive Education and Development, 3(1), 16-27. doi: 10.6007/IJARPED/v3-i1/500

Akbarzadeh, M., \& Fatemipour, H. (2014). Examining the match or mismatch between teaching style preferences and upper-intermediate EFL learners' learning style preferences. International Conference on Current Trends in ELT, 137-142. doi: 10.1016/j.sbspro.2014.03.399

Alkhatnai, M. (2011). Learning styles of EFL SAUDI college-level students in online and traditional educational environments. Indiana University of Pennsylvania: The School of Graduate Studies and Research Department of English.

Ananiadou, S., MacNaught, J., \& Thompson, P. (2012). The English language in the digital age. White Paper Series, META-Net.

Asba, A. A., Azman, H., \& Mustaffa, R. (2014). A match or mismatch between learning and teaching styles in science education. International Journal of Education and Research, 2(3), 1-14. https://www.researchgate.net/publication/261731609_A_Match_or_Mismatch_between_Learning_and_Teac hing_Styles_in_Science_Education

Awla, H. A. (2014). Learning styles and their relation to teaching styles. International Journal of Language and Linguistics, 2(3), 241-245. doi: 10.11648/j.ij11.20140203.23

Barzegar, F., \& Tajalli, G. (2013). Relationship between learning styles of advanced Iranian EFL learners and their achievment. Journal of Studies in Learning and Teaching English, 2(2), 1-20. http://jslte.iaushiraz.ac.ir/article_518962.html

Buangern, S., Latsanyphone, S., \& Hiragawa, Y. (2008). Gap between intended and acquired curriculum of English in Secondary schools in Laos. The Journal of Asia TEFL, 5(3),133-170.

Creswell, J. W. (2012). Educational research: conducting, and evaluating quantitative and qualitative research (4th ed.). Boston: Pearson.

Crystal, D. (2003). English as a global language (2nd edition). Cambridge University Press.

Dawson, C. (2002). Practical research methods: A user-friendly guide to mastering research techniques and projects. How to Books.

Donkoh, K. E., Eshun, E. S., \& Acquaye, V. N. A. (2015). Learning styles and factors affecting learning: Perception Of 2013/2014 final year post - diploma sandwich students of the department of basic education, University Of Education, Winneba (Uew), Ghana. Advances in Social Sciences Research Journal, 2(5). doi: 10.14738/assrj.25.1099

Dreyer, C., \& Walt, J. L. (1996). Learning and teaching styles: Empowering diverse learners in tertiary classrooms. Koers, 61(4), 469-482. doi: 10.4102/koers.v61i4.611

Dunn, R., \& Burke, K. (2005). LSCY: Research and implementation manual. New York: St. John's University.

Fang, S. (2012). A survey of teacher-student style mismatches. Higher Education of Social Science, 3(1), 5-12. 
Felder, R. M., \& Brent, R. (2005). Understanding student differences. Journal of Engineering Education, 94(1), 5772. doi: 10.1002/j.2168-9830.2005.tb00829.x

Fleming, N. (2012). Teaching and learning styles: VARK strategies. Neil D Fleming.

Gathumbi, A. M. W., Bwire, A. M., \& Roy-Campell, Z. M. (2014). Instructional practices and challenges in secondary English language teaching: Implications for development of benchmarks in Kenya. Research Journali's Journal of Education, 2(11), 1-16. http://www.researchjournali.com/view.php?id=1166

Ghada, S., Rima, B., Nola, B. N., \& Mona, N. (2011). A match or a mismatch between student and teacher learning style preferences. International Journal of English Linguistics, 1(1), 162-172. doi: 10.5539/ijel.v1n1p162

Gilakjani, A. P. (2012). Visual, auditory, kinaesthetic learning styles and their impacts on English language teaching. Journal of Studies in Education, 2(1), 104-113. doi: 10.5296/jse.v2i1.1007

Gokalp, M. (2013). The effect of students' learning styles to their academic success. Creative Education, 4(10), 627632. doi: $10.4236 /$ ce. 2013.410090

Grasha, A. F. (2002). Teaching with style: A practical guide to enhancing learning by understanding teaching \& learning styles. San Bernadina, CA: Alliance.

Guvenc, H. (2015). The relationship between teachers' motivational support and engagement versus disaffection. Educational Science: Theory and Practice, 15(3), 647-657. doi: 10.12738/estp.2015.3.2662

Jhaish, M. A. (2010). The relationship among learning styles, language learning strategies, and the academic achievement among the English majors at Al-Aqsa University. n.p: Department of the Requirement for the Master Degree of Education.

Karabuga, F. (2015). Match or mismatch between learning styles of prep-class EFL students and EFL teachers. Electronic Journal of Foreign Language Teaching, 12(2), 276-288.

Karthigenyan, K., \& Nirmala, K. (2013). Learning style preference of English language learners. Educationia Confab, 2(1), 134-140.

Khajloo, A. I. (2013). Problems in teaching and learning English for students. International Journal of Engineering Research and Development,7(3), 56-58.

Khanum, F. (2014). Learners' learning style preferences and teachers' awareness in the context of higher secondary level in Bangladesh. Global Journal of HUMAN-SOCIAL SCIENCE: A Arts \& Humanities - Psychology, 14(10), 1-4. https://socialscienceresearch.org/index.php/GJHSS/article/view/1221/1162

Khmakhien, A. (2012). Demystifying Thai EFL learners' perceptual learning style preferences. 3L: The Southeast Asian Journal of English Language Studies, $18(1), \quad 61-74$. https://www.researchgate.net/publication/266051596_Demystifying_Thai_EFL_Learners\%27_Perceptual_Le arning_Style_Preferences

Kirkpatrict, A. (2012). English in ASEAN: Implications for regional multilingualism. Journal of Multilingual and Multicultural Development, 33(4), 331-344. doi: 10.1080/01434632.2012.661433

Lin, H. C., \& Chien, C. S. (2010). An introduction to English teaching, a textbook for English educators. Saarbrucken, Germany.

Liu, F. (2012). A probe into the EFL learning style preferences of minority college students: An empirical study of Tujia EFL learners in Jishou University. Theory and Practice in Language Studies, 2(8), 1662-1667. doi:10.4304/tpls.2.8.1662-1667

MoES. (2015). Educational and sports sector development plan (2016-2020). https://data.opendevelopmentmekong.net/en/laws_record/education-and-sports-sector-development-plan2016-2020

Montgomery, S. M., \& Groat, L. N. (1998). Student learning styles and their implications for teaching. The Centre for Research on Learning and Teaching, The University of Michigan, No. 10. 
Mulalic, A., Shah, P. M., \& Ahmad, F. (2009). Learning-style preference of ESL students. AJTLHE, 1(2), 9-17. https://www.researchgate.net/publication/41389784_LEARNING-

STYLE_PREFERENCE_OF_ESL_STUDENTS

Oxford, R. L. (2003). Language learning styles and strategies: An overview. Learning Styles \& Strategies/Oxford, GALA.https://www.researchgate.net/publication/254446824_Language_learning_styles_and_strategies_An_ overview

Peacock, M. (2001). Match or mismatch? Learning styles and teaching styles in EFL. International Journal of Applied Linguistics, 11(1), 1-20. doi: 10.1111/1473-4192.00001

Prasonexay, S. (2006). English teaching methodology. Course book, Faculty of Education of National University of Laos. Xangkhou Printing House.

Ramayah, M., Nasrijal, N. H., Leong, C., Sivannadan, P., \& Letchumanan, T. (2011). Factors influencing the learning style preferences among business school students. Journal of Advanced Social Research, 229-243.

Razawi, N. A., Muslim, M., Razali, S. M. C., Husin, N., \& Samad, N. Z. A. (2011). Students' diverse learning styles in learning English as a second language. International Journal of Business and Social Science, 2(19), 179186.

Reid, J. M. (1987). The learning style preferences of ESL students. TESOL QUARTERLY, 21(1), 87-110. https://doi.org/10.2307/3586356

Reid, J. M. (1995). Learning styles in the ESL/EFL classroom. Boston: Heinle and Heinle.

Reyes, M. R., Brackett, M. A., Rivers, S. E., White, M., \& Salovey, P. (2012). Classroom emotional climate, student engagement, and academic achievement. Journal of Educational Psychology, 104(3), 700-712. doi: $10.1037 / \mathrm{a} 0027268$

Rossi-Le, L. (1989). Perceptual learning style preferences and their relationship to language learning strategies in adult students of English as a second language. (Unpublished doctoral dissertation). Drake University, Des Moines.

Sengsouliya, S. (2015). Instructional barriers faced by secondary school English teachers and their professional development needs: Secondary schools within Xaythany district, Vientiane capital. Journal of Scientific Research of Natioanl University of Laos.

Sengsouliya, S., Chatouphonexay, A., Phonekeo, S., \& Xaixanith, T. (2019). Probing university-level students' English learning style preferences: A case study of Laotian English majors. The Normal Light Journal, 13(1), 203-228. http://po.pnuresearchportal.org/ejournal/index.php/normallights/article/view/1241

Sengsouliya, S., Soukhavong, S., Silavong, N., Sengsouliya, S., \& Littlepage F. (2020). An investigation on predictors of student academic engagement. European Journal of Education Studies, 6(10), 124-142. https://oapub.org/edu/index.php/ejes/article/view/2793

Shim, J. M., \& Shur, A. M. (2018). Learning from ELLs' perspectives: Mismatch between ELL and teacher perspectives on ELL learning experiences. English Language Teaching, 11(1), 21-32. http://doi.org/10.5539/elt.v11n1p21

Shuib, M., \& Azizan, S. N. (2015). Learning style preferences among male and female ESL students in UniversitiSains Malaysia. The Journal of Educators, 13(2), 103-141. doi: 10.9743/JEO.2015.2.3

Souriyavongsa, et al. (2013). Factors causes students low English language learning: A case study in the National University of Laos. International Journal of English Language Education, 1(1), 179-192. doi: 10.5296/ijele.v1i1.3100

Stebbins, C. (1995). Culture-specific perceptual - learning - style preferences of post secondary students of English as a second language. In J. M. Reid (Ed.) Learning styles in the ESL/EFL classroom (pp. 108-117). New York: Heinle and Heinle Publishers. 
Tai, F. M. (2013). Adult EFL students' preferred learning styles and motivation. The Journal of Human Resource and Adult Learning, 9(2), 161-171.

Thongma Souriyavongsa, Mohamad Jafre Zainol Abidin, Rany Sam, Leong Lai Mei, \& Ithayaraj Britto. (2013). Investigating learning English strategies and English needs of undergraduate students at the National University of Laos. English Language Teaching, 6(10), 57-71. doi: 10.5539/elt.v6n10p57

Tien, N. Q., \& Cuong, N. C. (2015). English language teaching and learning in ASEAN countries and preparatory steps to integrate into the ASEAN Economic Community (AEC) 2015. International Integration, 24(34), 94100.

Vanstone, A., Cooke, D., Cameron, P., Lessard, R., Mosely-Williams, B., \& Wright, A. (2000). School improvement planning. A handbook for principals, teachers, and school councils. Education improvement commission. Ontario Legislative Library.

Vaseghi, R., Ramezani, A. E., \& Gholami, R. (2012). Language learning style preferences: A theoretical and empirical study. Advances in Asian Social Science, 2(2), 441-451. https://www.researchgate.net/publication/229088682_Language_Learning_Style_Preferences_A_Theoretical _and_Empirical_Study

Walter, C., \& Briggs, J. (2012). What professional development makes the most difference to teachers? Oxford University Press.

Wintergerst, A. C., DeCapua, A., \& Itzen, R. C. (2001). The construct validity of one learning styles instrument. System, 29(3), 385-403. doi: 10.1016/S0346-251X(01)00027-6

$\mathrm{Xu}, \mathrm{W}$. (2011). Learning styles and their implications in learning and teaching. Theory and Practice in Language Studies, 1(4), 413-416. doi: 10.4304/tpls.1.4.413-416

Yoshida, F., Conti, G. J., Yamaguchi, T., \& Iwasaki, T. (2014). Development of an instrument to measure teaching style in Japan: The teaching style assessment scale. Journal of Adult Education, 43(1), 11-18. https://eric.ed.gov/?id=EJ1047371

Zepke, N., Leach, L., \& Butler, P. (2010). Student engagement: What is it and what influences it? https://www.semanticscholar.org/paper/Student-Engagement\%3A-What-Is-It-and-What-Influences-ZepkeLeach/4994761abd887252840de3a33caeaa8b86dbe549

Zhou, M. (2012). Learning styles and teaching styles in college English teaching. International Education Studies, 4(1), 73-77. doi: 10.5539/ies.v4n1p73

Zywno, M. S., \& Waalen, J. K. (2002). The effect of individual learning styles on student outcomes in technologyenabled education. Global J. of Engng. Educ., 6(1), 35-44. https://www.semanticscholar.org/paper/The-Effectof-Individual-Learning-Styles-on-Student-Zywno-Waalen/6ea37c1c46379ae5c81320cf7ed8c87ca3c852b1 